\title{
Long-Term Groundwater Monitoring Plan for Ramona, Kansas
}

\author{
Environmental Science Division
}


About Argonne National Laboratory

Argonne is a U.S. Department of Energy laboratory managed by UChicago Argonne, LLC under contract DE-AC02-06CH11357. The Laboratory's main facility is outside Chicago, at 9700 South Cass Avenue, Argonne, Illinois 60439. For information about Argonne and its pioneering science and technology programs, see www.anl.gov.

\section{Availability of This Report}

This report is available, at no cost, at http://www.osti.gov/bridge. It is also available on paper to the U.S. Department of Energy and its contractors, for a processing fee, from:

U.S. Department of Energy

Office of Scientific and Technical Information

P.O. Box 62

Oak Ridge, TN 37831-0062

phone (865) 576-8401

fax (865) 576-5728

reports@adonis.osti.gov

\section{Disclaimer}

This report was prepared as an account of work sponsored by an agency of the United States Government. Reference herein to any specific commercial product, process, or service by trade name, trademark, manufacturer, or otherwise, does not necessarily constitute or imply its endorsement, recommendation, or favoring by the United States Government or any agency thereof. The views and opinions of document authors expressed herein do not necessarily state or reflect those of the United States Government or any agency thereof, Argonne National Laboratory, or UChicago Argonne, LLC. 


\section{Long-Term Groundwater Monitoring Plan for Ramona, Kansas}

by

Applied Geosciences and Environmental Management Section Environmental Science Division, Argonne National Laboratory

September 2012

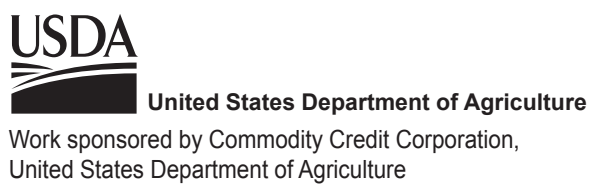




\section{Contents}

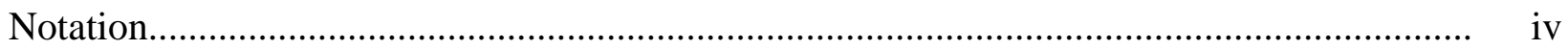

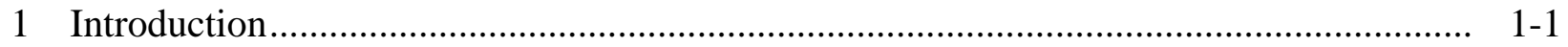

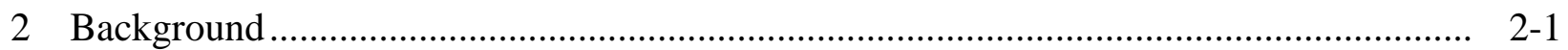

3 Monitoring Plan .....................................................................................................

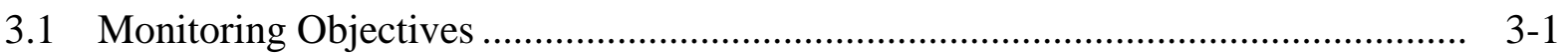

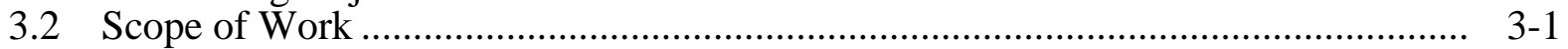

3.3 Sampling and Analysis .......................................................................................... 3-2

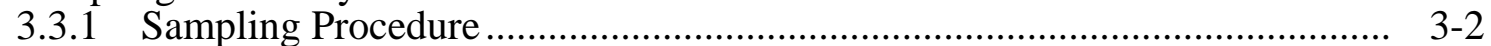

3.3.2 Sample Preservation and Analysis........................................................... 3-3

3.3.3 Documentation of Changes in Procedurees ………........................................ 3-3

3.4 Sampling and Reporting Schedule........................................................................... 3-3

3.4.1 Sampling Schedule........................................................................................ 3-3

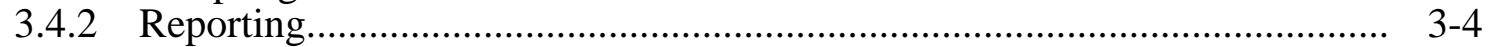

3.4.3 Sampling in Year 3 .................................................................................. 3-5

3.5 Quality Assurance and Quality Control.............................................................. 3-5

3.6 Waste Handling and Disposal ............................................................................ 3-7

3.7 Health and Safety ........................................................................................... 3-7

4 Contingency Plan ....................................................................................................... 4

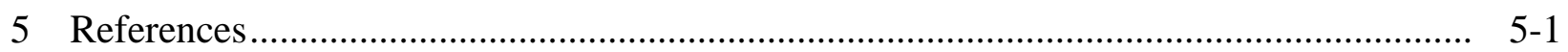

Tables

3.1 Construction details for wells to be sampled ……..................................................... 3-8

3.2 Analytical results for carbon tetrachloride, chloroform, and methylene chloride in groundwater samples collected from wells MW04-MW08 in 2006 and 2009.....

3.3 Analytical results for three private wells near the former CCC/USDA facility ........... 3-10

\section{Figures}

$2.1 \quad$ Location of Ramona, Kansas .............................................................................. 2-2

2.2 Locations of current and historical grain handling facilities at Ramona ...................... 2-3

2.3 Boundaries of the former CCC/USDA property.......................................................... 2-4

3.1 Locations of the wells to be sampled............................................................................. 3-11 
Ramona, Kansas, Long-Term Groundwater Monitoring Plan

Version 03, 09/05/12

3.2 Carbon tetrachloride concentrations detected in groundwater in April 2009, with water level contours constructed with data measured manually on

August 27, 2009 ……………………............................................................. 3-12

3.3 Route from Ramona to emergency medical services in Herington, Kansas.................. 3-13 
Ramona, Kansas, Long-Term Groundwater Monitoring Plan

Version 03, 09/05/12

\section{Notation}

ADS Final Agency Decision Statement

AGEM Applied Geosciences and Environmental Management

BGL below ground level

${ }^{\circ} \mathrm{C}$ degree(s) Celsius

CAS Corrective Action Study

CCC Commodity Credit Corporation

EPA U.S. Environmental Protection Agency

$\mathrm{ft} \quad$ foot (feet)

in. inch(es)

KDHE Kansas Department of Health and Environment

$\mu \mathrm{g} / \mathrm{L} \quad$ microgram(s) per liter

mi mile(s)

QA quality assurance

QC quality control

USDA U.S. Department of Agriculture

VOC volatile organic compound 


\section{Long-Term Groundwater Monitoring Plan for Ramona, Kansas}

\section{Introduction}

This Monitoring Plan describes a groundwater monitoring program for the property at Ramona, Kansas, on which a grain storage facility was formerly operated by the Commodity Credit Corporation of the U.S. Department of Agriculture (CCC/USDA). The purposes of this monitoring program are to accomplish the following:

- Satisfy requirements in the Final Agency Decision Statement (ADS) issued by the Kansas Department of Health and Environment (KDHE 2011b) for the former CCC/USDA facility.

- Substantiate the protectiveness of the corrective action described in the ADS.

- Monitor the stability of the contaminant plume.

- Confirm continued natural improvement in groundwater quality.

The planned monitoring activity is a component of the corrective action described in the ADS.

Details and background for the Ramona site investigation and the Ramona Corrective Action Study (CAS) were presented previously (Argonne 2007, 2011). The procedures to be followed for all monitoring activities at former CCC/USDA facilities in Kansas are described in the Master Work Plan (Argonne 2002), which includes complete details about the sampling, analyses, quality assurance, quality control, and reporting procedures associated with this Monitoring Plan. 


\section{Background}

Ramona, Kansas, is a small rural town with 187 residents (2010 Census). Located in the north-central portion of Marion County, Ramona is $104 \mathrm{mi}$ southwest of Topeka, Kansas, in the SE 1/4 of Section 2, Township 17 South, Range 3 East (Figure 2.1). Grain storage has occurred over the years at multiple locations in Ramona, including the former CCC/USDA facility, the facility operated by the Tampa Cooperative Association (the Co-op), and several privately owned locations along the east and south edges of the town (Figure 2.2). The Co-op operates north and west of the Union Pacific Railroad right-of-way.

The former CCC/USDA facility operated from 1950 to 1966 on one acre of leased land in the southeast part of Ramona. No structures remain on the property. The land is currently used for agriculture, specifically brome production. The property (506 East First Street; Figure 2.3) is currently privately owned and is located within the Ramona municipal boundaries. For tax purposes, the property is zoned residential. The principal water source for Ramona residents, including the property at 506 East First Street, is the Marion County Rural Water District \#1.

Sources of the groundwater contamination associated with the Co-op are under investigation. Investigations conducted by the CCC/USDA indicate that the concentrations of carbon tetrachloride in groundwater that can potentially be attributed to past CCC/USDA activities are decreasing and that groundwater impacts above threshold levels are localized and isolated from groundwater being impacted by the Co-op. Consistent with recommendations provided in the Ramona CAS and the ADS, the remedial action selected to address groundwater at the former CCC/USDA facility includes groundwater monitoring, as described in this Monitoring Plan. 


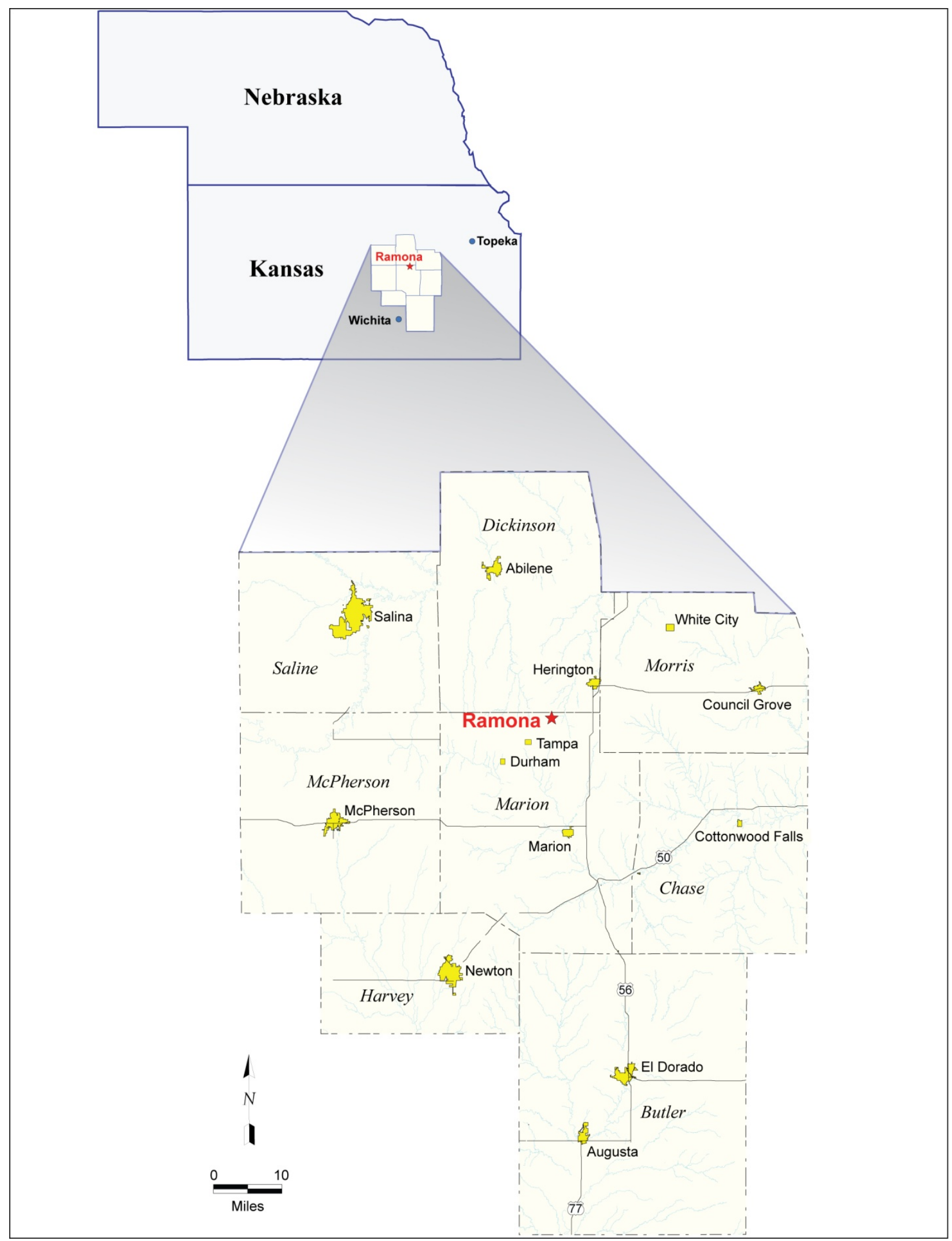

FIGURE 2.1 Location of Ramona, Kansas. 


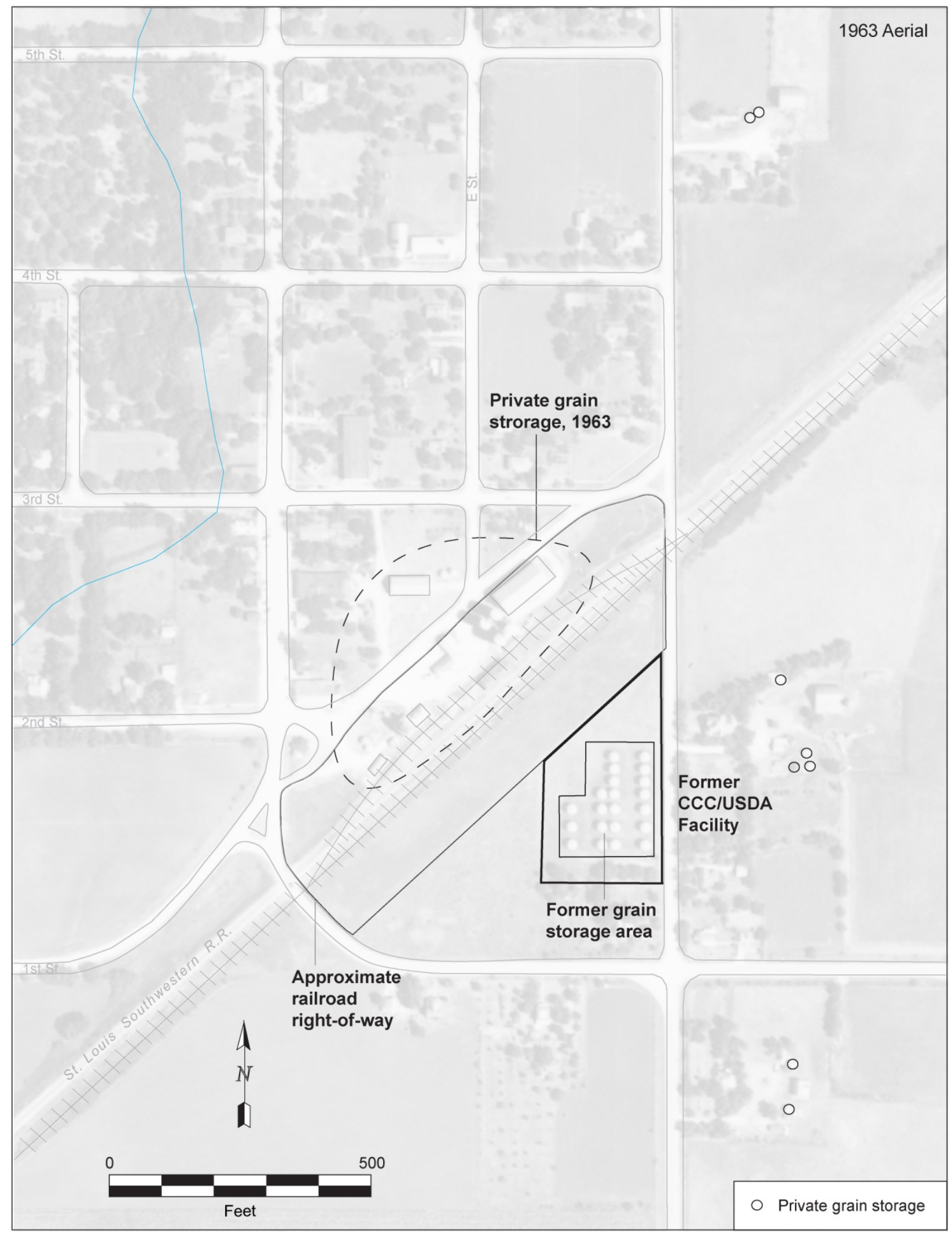

FIGURE 2.2 Locations of current and historical grain handling facilities at Ramona. Source of photograph: USGS (1963). 


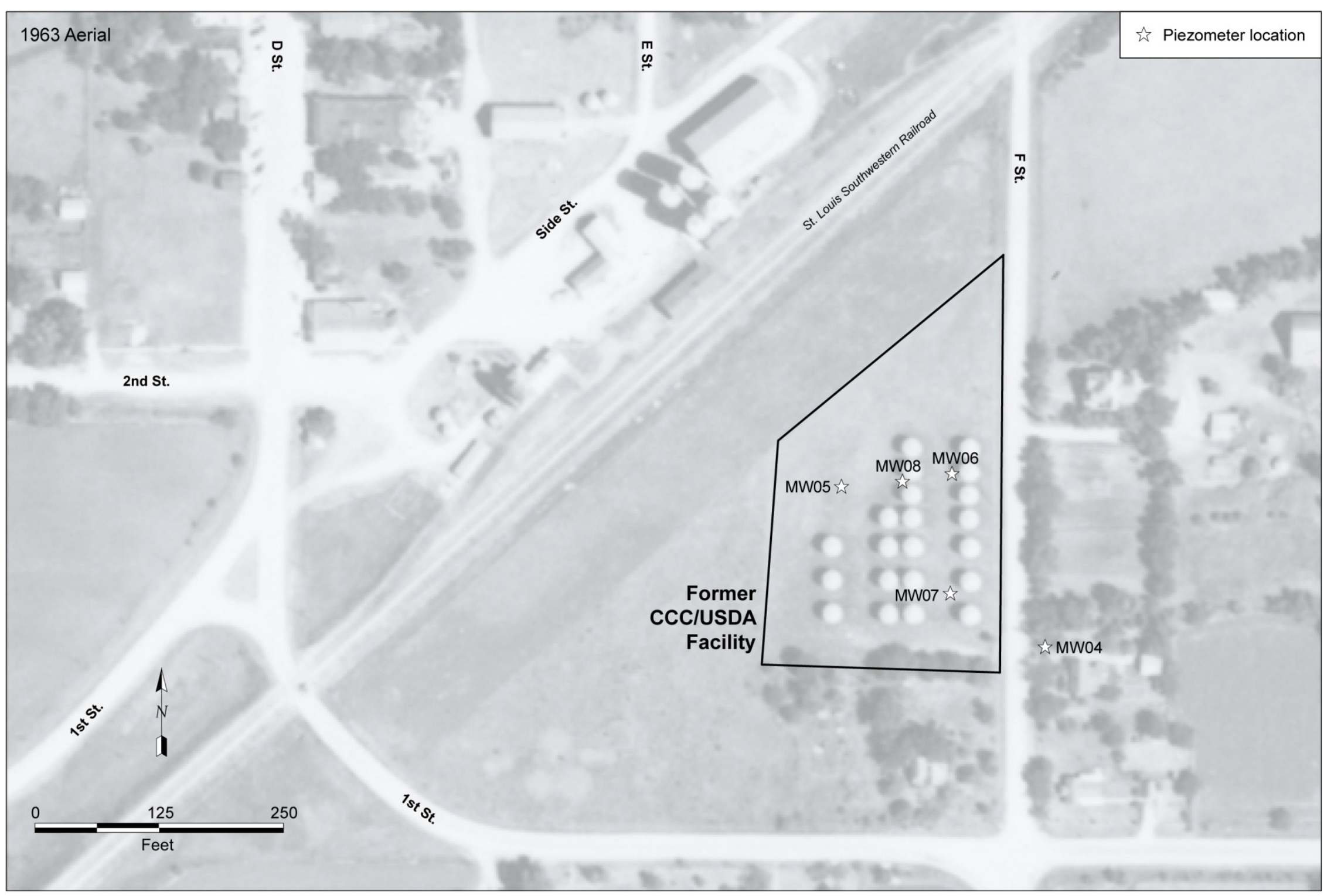

FIGURE 2.3 Boundaries of the former CCC/USDA property. Source of photograph: USGS (1963). 


\section{Monitoring Plan}

\subsection{Monitoring Objectives}

The objective of the monitoring program at Ramona is to collect and analyze groundwater samples periodically, in order to meet the following requirements of the ADS:

- Monitor plume stability.

- Substantiate continued natural improvement in water quality.

- Document the protectiveness of the corrective action.

\subsection{Scope of Work}

To satisfy the monitoring objectives, groundwater samples will be collected from monitoring wells MW04, MW05, MW06, MW07, and MW08 (Figure 3.1). These five wells will be sampled in years 1, 2, 3 (if needed), 5, and 10. Construction details for the five monitoring wells are in Table 3.1.

In addition, to obtain baseline results for the private wells nearest the former CCC/USDA facility, the Bura, Buxman, and Noeth private wells (Figure 3.1) will be sampled in year 1. The results for these wells will be evaluated by the CCC/USDA and KDHE project managers to determine whether and when these wells should be resampled. The available construction details for the three private wells are in Table 3.1.

The strategy for collecting groundwater samples will include a review of the historical analytical data for the monitoring wells (Table 3.2) and the private wells (Table 3.3). In each sampling event, wells that have previously shown no detectable concentrations of volatile organic compounds (VOCs) will be sampled first; those with past detections will be sampled in the order of lowest contamination to highest contamination.

Wells MW04, MW05, MW06, MW07, and MW08 were sampled in April 2009 and July 2006. Table 3.2 summarizes the analytical results for these events. Figure 3.2 illustrates the 
distribution of carbon tetrachloride at the former facility in April 2009 and water level contours constructed with data measured in August 2009. Sample results from April 2009 will be used to determine the order of well sampling during the initial monitoring event under the current monitoring program, in 2012.

The primary tasks in each monitoring well sampling event will be as follows:

1. Measure the static groundwater level and total depth in each well.

2. Collect a sample from each well for analysis of VOCs, including carbon tetrachloride, chloroform, and dichloromethane (methylene chloride).

\subsection{Sampling and Analysis}

\subsubsection{Sampling Procedure}

The well sampling will be conducted in accordance with procedures described in the Master Work Plan (Argonne 2002, Sections 6.1.2 and 6.2), as follows:

- The well number and the condition of the well completion will be documented in a log.

- The depth to groundwater and the total depth will be measured prior to sampling or purging.

- Because of the very low groundwater volume available at Ramona, two samples will be collected at each well, as follows:

- A first grab sample will be collected with a bailer, without purging. This sample will be analyzed if the second grab sample is inadequate for analysis purposes. 
- A Waterra pump will be used for purging of three volumes or until the well is dry. The volume of water purged will be recorded.

- A second grab sample will be collected with a bailer when sufficient water is available (immediately after purging or the next morning), without additional purging.

- Duplicates of a minimum of $10 \%$ of the total number of water samples collected will be sent to a second analytical laboratory for verification analysis under the U.S. Environmental Protection Agency (EPA) Contract Laboratory Program. At least one verification sample will be submitted for each monitoring event.

\subsubsection{Sample Preservation and Analysis}

Samples intended for analysis of VOCs (including carbon tetrachloride and chloroform) will be collected in laboratory-approved containers. The containers will be sealed and placed immediately in a cooler at $4^{\circ} \mathrm{C}$. The samples will be shipped with overnight delivery to the Applied Geosciences and Environmental Management (AGEM) Laboratory at Argonne for analysis with a modification of EPA Method 524.2 (EPA 1995).

\subsubsection{Documentation of Changes in Procedures}

All activities conducted and any deviations from normal procedures will be documented in the log. Approval for deviations or modifications will be sought from the CCC/USDA and KDHE project managers.

\subsection{Sampling and Reporting Schedule}

\subsubsection{Sampling Schedule}

This sampling plan will be implemented within 60 days of KDHE approval. 
Monitoring events will be conducted in years 1, 2, 3 (if needed), 5, and 10. As the CAS provides (Argonne 2011, Section 4.2), "if monitoring results in years 1 and 2 indicate an improvement in water quality, the CCC/USDA and the KDHE could agree to omit the year 3 monitoring event.” The CAS was approved by the KDHE (2011a).

The KDHE will be notified 14 days prior to each sampling event. After the groundwater data generated during the sampling event have been evaluated and validated, a report documenting the sampling activities and presenting the sampling results will be prepared and submitted to the KDHE within 90 days of the completion of field work.

\subsubsection{Reporting}

The monitoring report will follow the guidelines for site monitoring established by the KDHE (2005). Accordingly, the report will include the following, at a minimum:

- A narrative of the work performed

- Static water level measurements

- Laboratory analytical data reports

- Summary tables presenting current and historical site data

- Maps depicting the sample locations, groundwater gradient, and contaminant levels

- Descriptions of any deviations from the approved sampling procedures

- Field documentation

- Quality assurance and quality control data 


\subsubsection{Sampling in Year 3}

The report of the year 2 sampling will include an analysis of observations to date and a recommendation as to whether the year 3 sampling is technically warranted or should be omitted.

\subsection{Quality Assurance and Quality Control}

Included in this section is a summary of methods that will be followed to meet quality assurance/quality control (QA/QC) standards. Descriptions of all QA/QC methods are in Section 4.2 of the Master Work Plan (Argonne 2002). That document should be consulted for a more detailed narrative of the QA/QC procedures.

The QA/QC requirements during field sampling are as follows:

- Ensure that samples collected are representative of current site conditions.

- Ensure that sample volume is sufficient to meet the monitoring goals.

- Ensure that field instrument calibration procedures are followed and that the appropriate quality control samples are collected. For this project, a minimum of one field blank, one rinsate sample, one trip blank, and one field replicate will be collected, in addition to a minimum of one verification sample (and additional verification samples at a rate of $10 \%$ of total samples).

- $\quad$ Record all details of the work in a log.

- To the extent possible, use disposable or dedicated sampling equipment at each sampling location.

- Between wells, thoroughly wash all non-disposable sampling equipment with a nonionic detergent in water, then rinse with water.

- Collect groundwater samples according to the procedures specified in Section 3.3.1. 
- Label sample containers as instructed in the Master Work Plan (Argonne 2002, Appendix D, Section D.1.4). At a minimum, include the following information: sample identifier, date, time, preservative, and intended analysis. Use preprinted sample labels for this task.

- Complete a preprinted chain-of-custody record as instructed in the Master Work Plan (Argonne 2002, Appendix D, Section D.1.5).

- Appropriately pack and seal shipping containers to ensure that chain of custody is maintained.

- Use preprinted shipping labels for sample containers being sent to laboratories for off-site analyses.

Laboratory QA/QC procedures are designed to ensure that sample integrity is maintained and that sample analysis is reproducible. This will be accomplished, in part, by verifying that laboratory-related field documentation is complete and that procedures have been followed with regard to chain-of-custody records, sample storage, and sample holding times. In addition, laboratory procedures, equipment calibration, and performance standards (reproducibility, standards, spikes recoveries, etc.) will be reviewed and documented in the monitoring report discussed in Section 3.4.2.

Groundwater samples received at the AGEM Laboratory will be analyzed for VOCs as indicated in Section 3.3.2, within the specified holding times.

For verification purposes, samples selected in the field ( $10 \%$ of the total or a minimum of one sample) will be analyzed by a second laboratory with the EPA's Contract Laboratory Program methodology.

The QA records completed during the project will be maintained by the QA/QC coordinator and stored with the project files. 


\subsection{Waste Handling and Disposal}

Wastewater generated during sampling will be placed temporarily in containers on the site and sampled for VOCs analyses. The water will be combined with wastewater from other sites in Kansas for disposal in accordance with KDHE regulations.

\subsection{Health and Safety}

The general health and safety plan for use during this project, in the Master Work Plan (Argonne 2002, Section 3), addresses all anticipated safety issues for the activities at the Ramona site. Specific emergency information for Ramona is provided here.

Ramona has emergency 911 service. All emergency calls, including police, fire, and ambulance calls, are directed for an appropriate response from this number. No emergency medical facilities exist at Ramona. The nearest hospital with emergency medical facilities is in Herrington, Kansas. Driving directions to the hospital and a map showing the route are in Figure 3.3. 
TABLE 3.1 Construction details for wells to be sampled.

\begin{tabular}{|c|c|c|c|c|c|c|c|}
\hline \multirow[b]{2}{*}{ Well } & \multirow[b]{2}{*}{$\begin{array}{c}\text { Kansas } \\
\text { Registration } \\
\text { Numbera }\end{array}$} & \multirow[b]{2}{*}{$\begin{array}{l}\text { Diameter } \\
\text { (in.) }\end{array}$} & \multicolumn{4}{|c|}{ Depth (ft BGL) } & \multirow[b]{2}{*}{$\begin{array}{l}\text { Casing } \\
\text { Elevation } \\
\text { (ft AMSL) }\end{array}$} \\
\hline & & & $\begin{array}{l}\text { Screen } \\
\text { Interval }\end{array}$ & $\begin{array}{c}\text { Filter } \\
\text { Pack } \\
\text { Interval }\end{array}$ & $\begin{array}{l}\text { Water } \\
\text { Level }\end{array}$ & Total & \\
\hline \multicolumn{8}{|c|}{ Monitoring wells } \\
\hline MW04 & 392881 & 1 & $45-55$ & $44-55$ & 55.5 & 55 & 1439.52 \\
\hline MW05 & 393241 & 1 & $45-55$ & $44-55$ & 55.1 & 55 & 1435.19 \\
\hline MW06 & 392883 & 1 & $45-55$ & 44-55 & 55.6 & 55 & 1436.63 \\
\hline MW07 & 392884 & 1 & $45-55$ & $44-55$ & 55.7 & 55 & 1438.15 \\
\hline MW08 & 392885 & 1 & $45-55$ & 44-55 & 55.5 & 55 & 1435.72 \\
\hline \multicolumn{8}{|c|}{ Private wells } \\
\hline Bura & - & - & - & - & - & $65^{b}$ & 1439.14 \\
\hline Buxman & - & - & - & - & - & 75 & - \\
\hline Noeth $^{\mathrm{c}}$ & - & - & - & - & - & - & - \\
\hline
\end{tabular}

a Registration number in the Kansas Geological Survey well registration database.

b Information provided by well owner.

c Formerly owned by Roger Chartier. 
TABLE 3.2 Analytical results for carbon tetrachloride, chloroform, and methylene chloride in groundwater samples collected from wells MW04-MW08 in 2006 and 2009. ${ }^{\text {a }}$

\begin{tabular}{|c|c|c|c|c|c|c|c|}
\hline \multirow[b]{2}{*}{ Location } & \multirow[b]{2}{*}{ Sample } & \multirow[b]{2}{*}{$\begin{array}{c}\text { Sample } \\
\text { Date }\end{array}$} & \multicolumn{2}{|c|}{ Depth (ft BGL) } & \multicolumn{3}{|c|}{ Concentration $(\mu \mathrm{g} / \mathrm{L})$} \\
\hline & & & $\begin{array}{l}\text { Screen } \\
\text { Interval }\end{array}$ & Groundwater & $\begin{array}{c}\text { Carbon } \\
\text { Tetrachloride }\end{array}$ & Chloroform & $\begin{array}{c}\text { Methylene } \\
\text { Chloride }\end{array}$ \\
\hline MW04 & RATI16-W-21449 & $7 / 13 / 06$ & $45-55$ & 51 & $N D^{b}$ & ND & ND \\
\hline MW04 & RAMW4-W-21466 & $4 / 27 / 09$ & $45-55$ & 46 & ND & ND & ND \\
\hline MW04 & RAMW4-W-21472 & $4 / 28 / 09$ & $45-55$ & & ND & ND & ND \\
\hline MW05 & RATI17-W-21450 & $7 / 13 / 06$ & $45-55$ & 47 & $0.9 \mathrm{Jc}$ & $0.3 \mathrm{~J}$ & ND \\
\hline MW05 & RAMW5-W-21467 & 4/27/09 & $45-55$ & 47 & 2.1 & ND & ND \\
\hline MW05 & RAMW5-W-21473 & $4 / 28 / 09$ & $45-55$ & & 1.7 & $0.4 \mathrm{~J}$ & ND \\
\hline MW06 & RATI18-W-21452 & $7 / 13 / 06$ & $45-55$ & 50 & 1.8 & 1.1 & ND \\
\hline MW06 & RAMW6-W-21468 & $4 / 27 / 09$ & $45-55$ & 49 & 1.5 & ND & ND \\
\hline MW06 & RAMW6-W-21474 & $4 / 28 / 09$ & $45-55$ & & 2.4 & $0.3 \mathrm{~J}$ & ND \\
\hline MW07 & RATI19-W-21453 & $7 / 13 / 06$ & $45-55$ & 50 & 6.3 & 1.6 & ND \\
\hline MW07 & RAMW7-W-21469 & 4/27/09 & $45-55$ & 49 & 12 & 1.7 & ND \\
\hline MW07 & RAMW7-W-21475 & $4 / 28 / 09$ & $45-55$ & & 10 & 1.7 & ND \\
\hline MW08 & RATI20-W-21451 & $7 / 13 / 06$ & $45-55$ & 47 & $0.7 \mathrm{~J}$ & ND & ND \\
\hline MW08 & RAMW8-W-21470 & 4/27/09 & $45-55$ & 47 & ND & ND & ND \\
\hline MW08 & RAMW8-W-21476 & $4 / 28 / 09$ & $45-55$ & & $0.8 \mathrm{~J}$ & ND & ND \\
\hline
\end{tabular}

a Because of the low productivity of the monitoring wells at Ramona, the following sampling strategy was used in April 2009: (1) a sample of the water available in each well casing was obtained; (2) the well was purged of three well volumes or to the extent possible; and (3) a second sample was collected after the well had recovered.

b ND, not detected at instrument detection limit of $0.1 \mu \mathrm{g} / \mathrm{L}$.

c Qualifier J indicates an estimated concentration below the purge-and-trap method quantitation limit of $1.0 \mu \mathrm{g} / \mathrm{L}$. 
TABLE 3.3 Analytical results for three private wells near the former CCC/USDA facility.

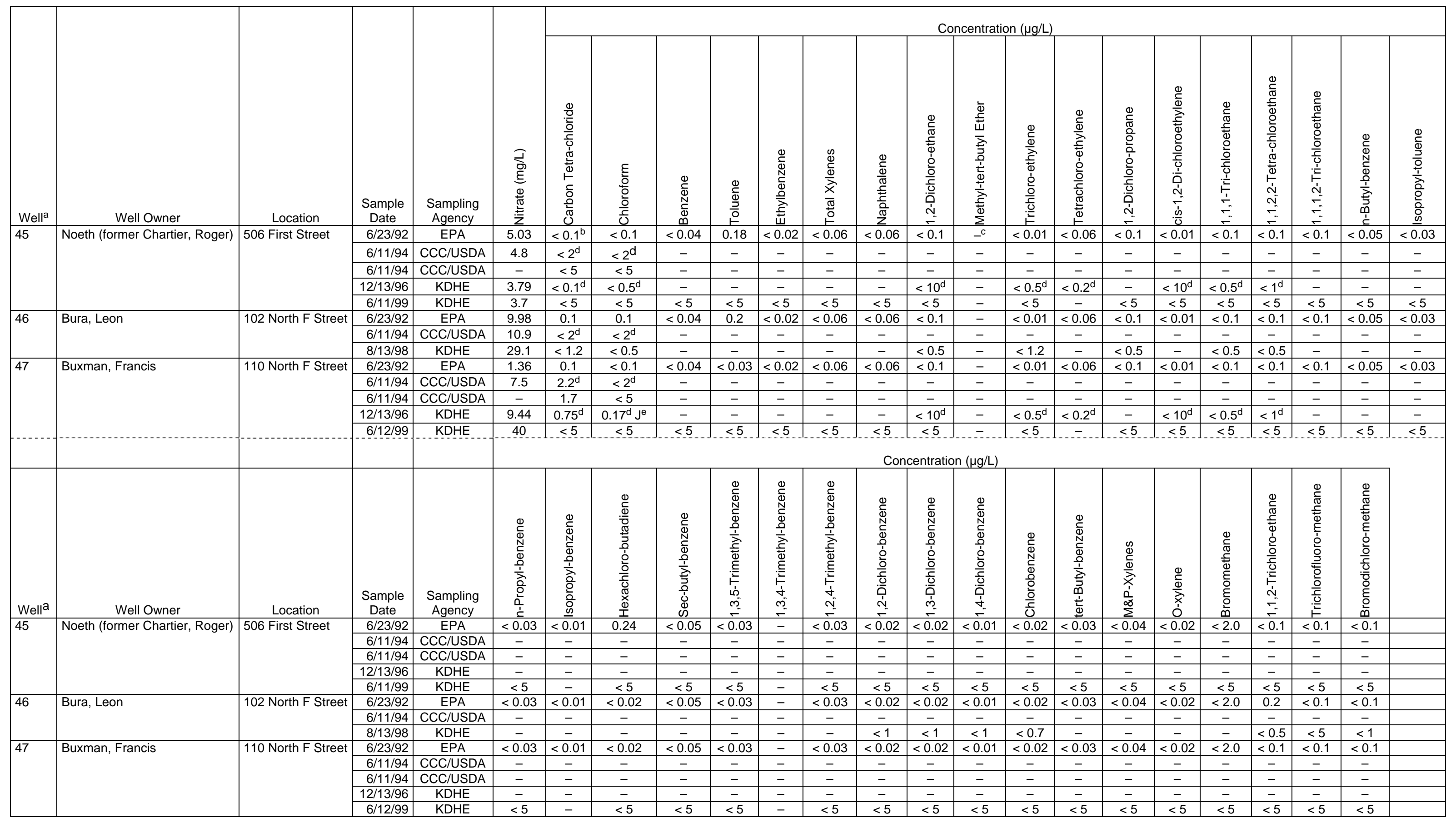

Well identification numbers are as shown in Table A.1, Appendix A, of the Work Plan (Argonne 2005),

b $<0.1$, not detected above the limit indicated.

c No data available.

d On-site testing.

e Compound detected at a level below the on-site laboratory's reporting limit and therefore qualified as estimated. 


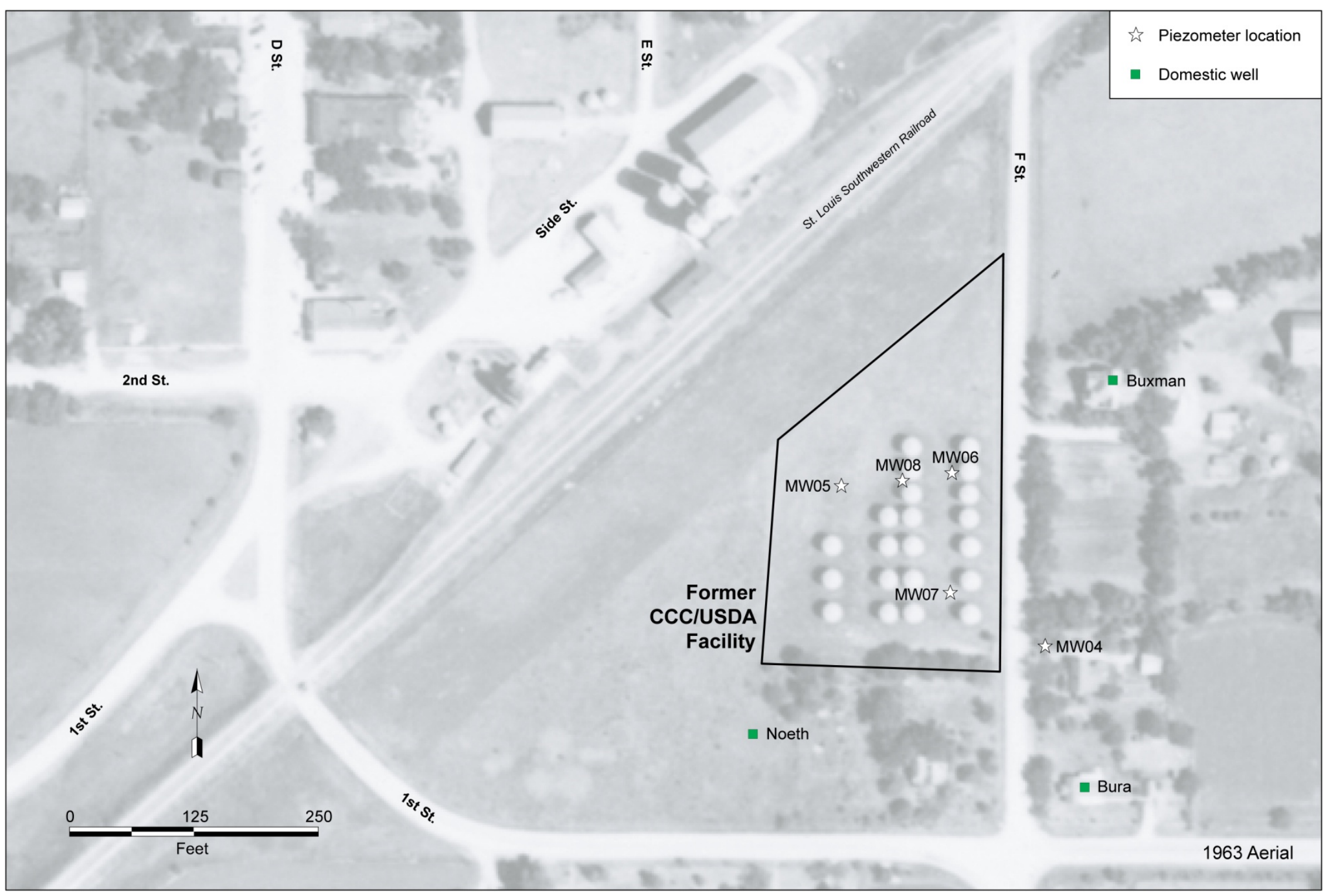

FIGURE 3.1 Locations of the wells to be sampled. Source of photograph: USGS (1963). 


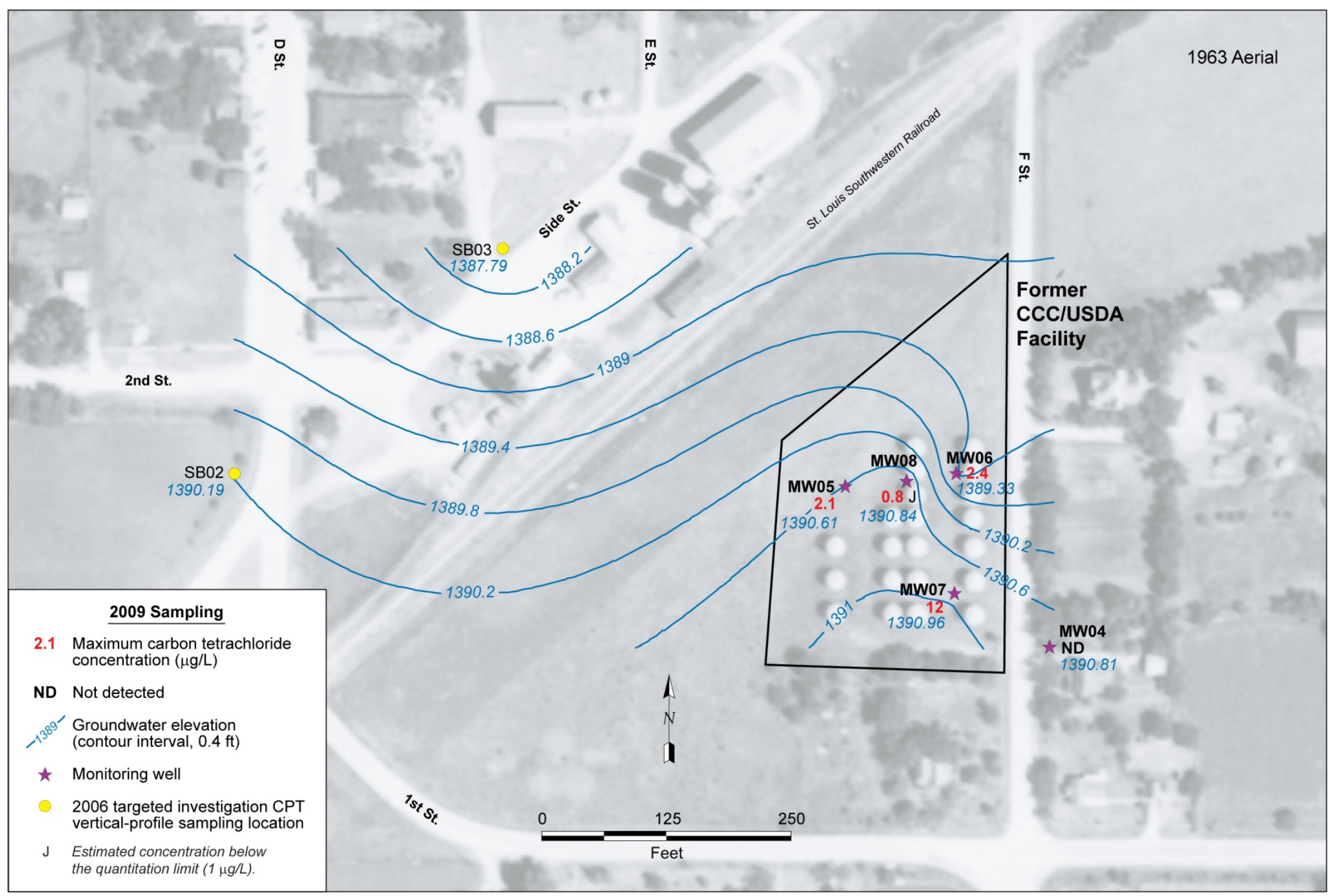

FIGURE 3.2 Carbon tetrachloride concentrations detected in groundwater in April 2009, with water level contours constructed with data measured manually on August 27, 2009. Source of photograph: USGS (1963). 


\section{Directions from Ramona to Herington Municipal Hospital in Herington, Kansas}

- From Ramona former CCC facility, go east on 360th Rd. to US 56E/US $77 \mathrm{~N}$ (approximately 6 miles).

- Turn left onto $56 \mathrm{E} / 77 \mathrm{~N}$.

- Continue to follow US 77N (also Wolf Rd. in Herington) for 6 miles to E. Helen Street, Herington.

- Turn left onto E. Helen St.

- Proceed approximately $1 / 2$ mile; hospital is on the left.

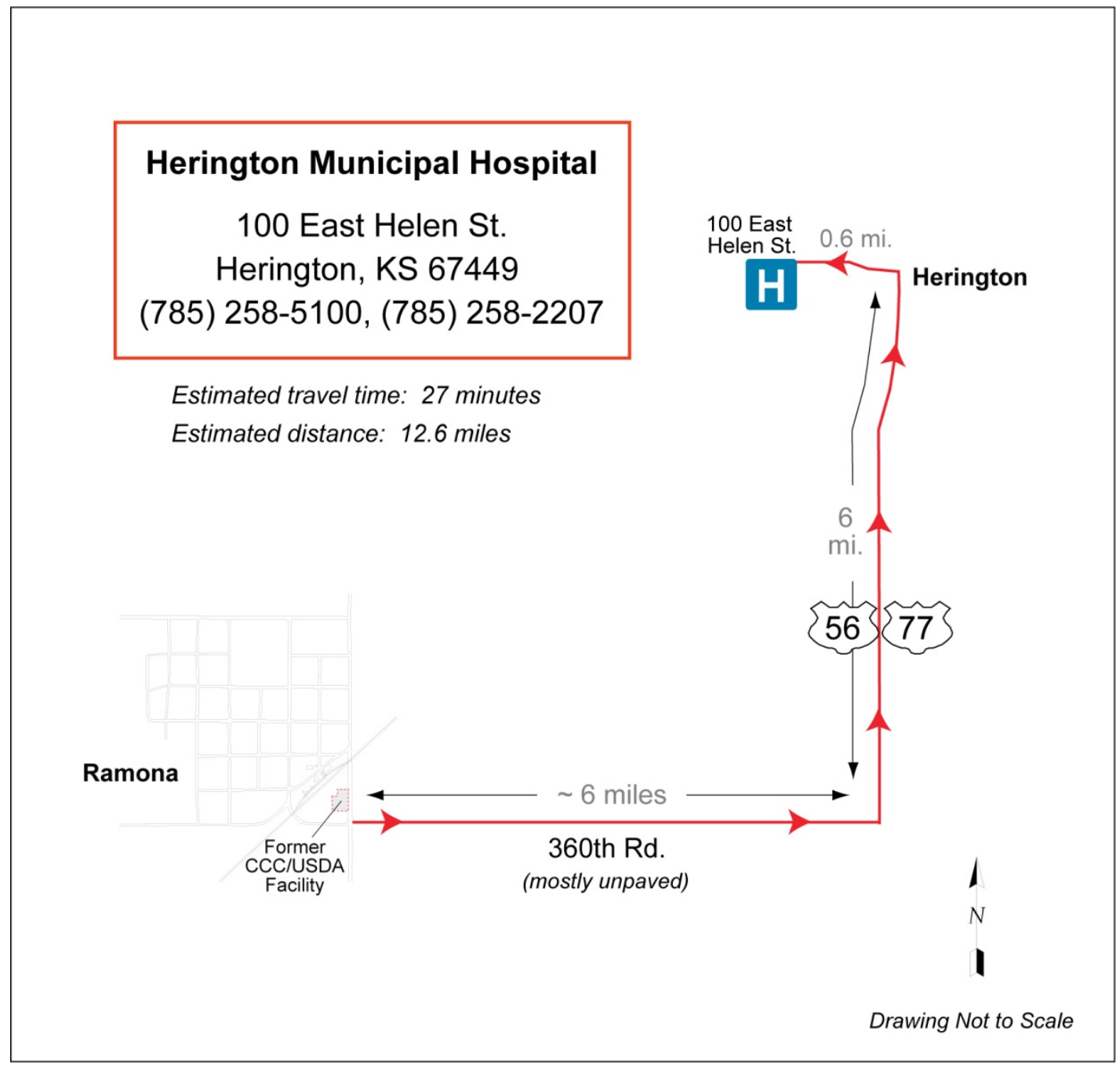

FIGURE 3.3 Route from Ramona to emergency medical services in Herington, Kansas. 


\section{Contingency Plan}

The CCC/USDA defines the following contingency plan:

- Groundwater monitoring results will be reviewed on a routine basis to evaluate contaminant trends and to determine whether additional monitoring wells and/or other modifications to the monitoring program (e.g., sampling of new or existing domestic wells) are necessary.

- If an evaluation of monitoring results indicates that contaminant concentrations in groundwater are not decreasing, the CCC/USDA will review the current site conditions and historical data to determine the most appropriate approach for addressing the contamination, including in situ treatment, groundwater extraction and treatment, and other currently available technologies (Argonne 2011). 


\section{References}

Argonne, 2002, Final Master Work Plan: Environmental Investigations at Former CCC/USDA Facilities in Kansas, 2002 Revision, ANL/ER/TR-02/004, prepared for the Commodity Credit Corporation, U.S. Department of Agriculture, by Argonne National Laboratory, Argonne, Illinois, December.

Argonne, 2005, Final Work Plan: Investigation of Potential Contamination at the Former CCC/USDA Facility in Ramona, Kansas, ANL/ER/TR-05/002, prepared for Commodity Credit Corporation, U.S. Department of Agriculture, Washington, D.C., by Argonne National Laboratory, Argonne, Illinois, November.

Argonne, 2007, Final Report: Results of the 2006 Investigation of Potential Contamination at the Former CCC/USDA Facility in Ramona, Kansas, ANL/EVS/AGEM/TR-07-10, prepared for Commodity Credit Corporation, U.S. Department of Agriculture, Washington, D.C., by Argonne National Laboratory, Argonne, Illinois, September.

Argonne, 2011, Final Corrective Action Study for the Former CCC/USDA Facility in, Ramona Kansas ANL/EVS/AGEM/TR-10-05, prepared for Commodity Credit Corporation, U.S. Department of Agriculture, Washington, D.C., by Argonne National Laboratory, Argonne, Illinois, March.

EPA, 1995, Method 524.2: Measurement of Purgeable Organic Compounds in Water by Capillary Column Gas Chromatography/Mass Spectrometry, Revision 4.1, edited by J.W. Munch, National Exposure Research Laboratory, Office of Research and Development, U.S. Environmental Protection Agency, Cincinnati, Ohio.

KDHE, 2005, Scope of Work for Site Monitoring, Policy BER-RS-036, Remedial Section, Bureau of Environmental Remediation, Kansas Department of Health and Environment, Topeka, Kansas, December 28 (http://www.kdheks.gov/ber/policies/BER_RS_036_SOW.pdf).

KDHE, 2011a, letter from M. Townsend (Bureau of Environmental Remediation, Kansas Department of Health and Environment, Topeka) to C. Roe (Commodity Credit Corporation, U.S. Department of Agriculture, Washington, D.C.), regarding the Ramona CAS, April 14. 
KDHE, 2011b, Final Agency Decision Statement for the Former CCC/USDA Facility in Ramona, Kansas, Bureau of Environmental Remediation, Kansas Department of Health and Environment, Topeka, Kansas, December 1.

USGS, 1963, aerial photograph AYG-2DD-253, U.S. Geological Survey, Washington, D.C., August 2. 
Argonne

Environmental Science Division

Argonne National Laboratory

9700 South Cass Avenue, BIdg. 203

Argonne, IL 60439-4843

www.anl.gov 